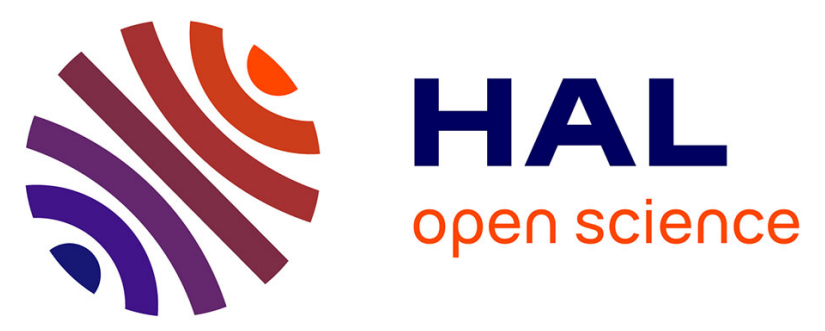

\title{
Response to Better for Some, Maybe Not for All: A Response to Preemptive Transfusion and Infusion Strategy in Children during Craniofacial Reconstruction
}

Paolo Cortellazzi, Dario Caldiroli, Massimo Lamperti, Monica Bricchi, Laura Valentini

\section{To cite this version:}

Paolo Cortellazzi, Dario Caldiroli, Massimo Lamperti, Monica Bricchi, Laura Valentini. Response to Better for Some, Maybe Not for All: A Response to Preemptive Transfusion and Infusion Strategy in Children during Craniofacial Reconstruction. Pediatric Anesthesia, 2010, 20 (7), pp.675. 10.1111/j.1460-9592.2010.03321.x . hal-00552643

\section{HAL Id: hal-00552643 https://hal.science/hal-00552643}

Submitted on 6 Jan 2011

HAL is a multi-disciplinary open access archive for the deposit and dissemination of scientific research documents, whether they are published or not. The documents may come from teaching and research institutions in France or abroad, or from public or private research centers.
L'archive ouverte pluridisciplinaire HAL, est destinée au dépôt et à la diffusion de documents scientifiques de niveau recherche, publiés ou non, émanant des établissements d'enseignement et de recherche français ou étrangers, des laboratoires publics ou privés. 


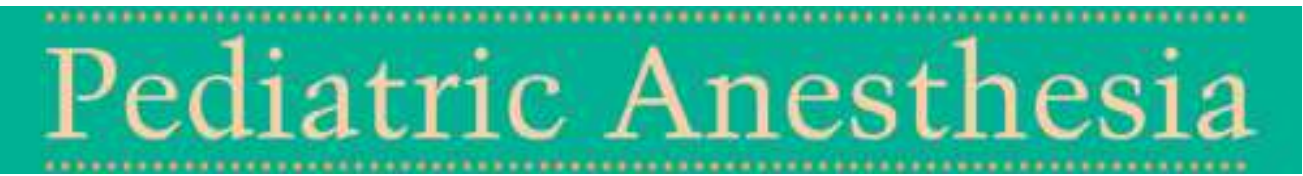

\section{Response to Better for Some, Maybe Not for All: A Response to Preemptive Transfusion and Infusion Strategy in Children during Craniofacial Reconstruction}

\begin{tabular}{|r|l|}
\hline Journal: & Pediatric Anesthesia \\
\hline Manuscript ID: & PAN-2010-0136 \\
\hline Manuscript Type: & Letter \\
\hline Date Submitted by the \\
Author: & $18-$ Mar-2010 \\
\hline Complete List of Authors: & $\begin{array}{l}\text { Cortellazzi, Paolo; Istituto Neurologico Carlo Besta, } \\
\text { Neuroanesthesia } \\
\text { Caldiroli, Dario; Istituto Neurologico Carlo Besta, Neuroanesthesia } \\
\text { Lamperti, Massimo; Istituto Neurologico Carlo Besta, } \\
\text { Neuroanesthesia } \\
\text { Bricchi, Monica; Istituto Neurologico Carlo Besta, Neuroanesthesia } \\
\text { Valentini, Laura; Istituto Neurologico Carlo Besta, Neurosurgery }\end{array}$ \\
\hline Key Words: & \begin{tabular}{l} 
craniosynostosis, blood loss, outcome \\
\hline
\end{tabular} \\
\hline
\end{tabular}

\section{s ScholarONE" \\ Manuscript Central}


Title: Response to Better for Some, Maybe Not for All: A Response to

\section{Preemptive Transfusion and Infusion Strategy in Children during Craniofacial}

\section{Reconstruction}

Paolo Cortellazzi MD §, Dario Caldiroli MD §, Massimo Lamperti MD §, Monica Bricchi MD § and Laura Valentini MD ${ }^{\circ}$

$\S$ Department of Anesthesiology, Istituto Nazionale Neurologico Carlo Besta, Milan, Italy

${ }^{\circ}$ Department of Pediatric Neurosurgery, Istituto Nazionale Neurologico Carlo Besta, Milan, Italy

Contact author:

Paolo Cortellazzi, MD

pcortellazzi@istituto-besta.it

Paolo Cortellazzi, MD

Department of Anesthesiology

Istituto Nazionale Neurologico Carlo Besta

Via Celoria, 11

I-20133 Milano MI

Italy 
Sir-- We appreciate the comment to our presentation by Ririe et al. We agree that some observations regarding the risk of unnecessary transfusions by adopting the pre-emptive infusion trasfusion strategy (EPTI) have to be explained. For this reason, we'll give more details in order to better understand our management of blood loss of the earlier cranioplasties (Control group) and of EPTI group.

Median intra-operative blood losses of Control group were 20\% of estimated red cell volume (95\% CI: 4\%-73\%) while perioperatory blood losses were $50 \%$ (95\% CI: 25\%-120\%). Most infants of this series showed post-operative hematocrit values lower than $20 \%$ and, given their unstable clinical conditions, the clinicians transfused blood products in 22 of them. Two out of three infants were not transfused but had hematocrit values of $15 \%$ and $18 \%$ respectively eight hours following surgery. Only one infant of EPTI group had an $\mathrm{Ht}$ value at the end of surgery higher than basal $\mathrm{Ht}$ (34\% vs. 27\%); perioperatory blood losses in the same group were $71 \%$ of ERCV (95\% CI: 40\%-163\%). During the post-operative period and at discharge from the hospital, hematocrit was never lower than $20 \%$. In this group, the outcome measures considered in our study (i.e. feeding time lower than seven hours to the end of surgery, length of stay in the intensive care unit and post-operative length of stay in hospital) were considerably better. Jonas et al. (19) found that haemodilution to a hematocrit thought to be safe (i.e. 21\%), in infants undergoing hypothermic cardiopulmonary by-pass, was associated with adverse perioperative and developmental outcome (1). Perhaps in our study better outcomes in the EPTI group may have the same source. The EPTI strategy may help reach normovolemia and a perioperatory stable hematocrit higher than $20 \%$ in hemorrhagic surgery of infants minimizing the effects of differences in anaesthesiologists and in patients.

On the other hand, where predicted blood losses are lower than $20 \%$, with extreme values no higher than $20 \%$, a conservative approach could be preferred supporting preoperative erythropoietin and autologous normovolemic donation in selected cases. Without doubt, less invasive surgical techniques (2-4) in comparison to the traditional procedure adopted by our team (2) are crucial to reduce perioperatory blood loss. This may result both in stable hematocrit values without homologous transfusions practices and in an easier approach to replace fluid and blood when infants require it. Beyond these advantages, there is still a lack of evidence on the final results for all craniosynostoses treatment, in terms of 


\section{cephalic index and 3D-head CT scan between CVR, spring-mediated cranioplasty and endoscopic strip craniotomy.}

\section{References}

1. Jonas RA, Wypij D, Roth SJ et al. The influence of haemodilution on outcome after hypothermic cardiopulmonary bypass: results of a randomized trial in infants. $J$ Thorac Cardiovasc Surg 2003; 126: 1765-74.

2. Podda S, Wolfe A, Kordestani RK, Panchal J, Vela G. Craniosynostosis management. U pdated June 28, 2006. Avaiable at: http://www.emedicine.com/plastic/topic534.htm. Accessed March 2010.

3. Lauritzen C, Sugawara Y, Kocabalkan O, Olsson R. Spring mediated dynamic craniofacial reshaping: case report. Scan J Plast Reconstr Surg Hand Surg 1998;32:331-8

4. Jemenez D, Barone C, Cartwright C, BAker C. Early management using endoscopicassisted strip craniectomis and cranial orthotic molding therapy. Pediatrics 2002;110:97104 